\title{
Effects of dietary inclusion of Opuntia ficus-indica on the glycemia and productive performance in lactating sows
}

\author{
G. Ordaz ${ }^{1}$, A. Juárez ${ }^{1}, K_{\text {K. }}$ Vargas $^{2}$, R.E. Pérez ${ }^{3 \#}$ \& R. Ortiz \\ ${ }^{1}$ Instituto de Investigaciones Agropecuarias y Forestales-UMSNH, Km 9.5 Carretera Morelia-Zinapécuaro, Tarímbaro, \\ P.C., 58920, México \\ ${ }^{2}$ Departamento de Ciencias Médicas, División de Ciencias de la Salud, Universidad de Guanajuato, Guanajuato, P.C. \\ 37000, México \\ ${ }^{3}$ Facultad de Químico Farmacobiología-UMSNH, Morelia, P.C., 581030, México \\ ${ }^{4}$ Facultad de Medicina Veterinaria y Zootecnia-UMSNH, Morelia, P.C., 581030, México
}

(Received 7 January 2019; Accepted 5 June 2017; First published online 1 October 2019)

\author{
Copyright resides with the authors in terms of the Creative Commons Attribution 4.0 South African License. \\ See: http://creativecommons.org/licenses/by/4.0/za \\ Condition of use: The user may copy, distribute, transmit and adapt the work, but must recognize the authors and \\ the South African Journal of Animal Science.
}

\begin{abstract}
Sows with increased blood glucose during late gestation may have decreased feed intake in lactation. Supplying dietary fibre to the sow reportedly modulates blood glucose and improves feed intake. The objective of this study was to evaluate the effects of dietary inclusion of cactus (Opuntia ficus-indica) on the regulation of blood glucose and productive performance in lactating sows. Data from 52 hybrid sows were analysed. The sows were divided into two groups, namely a control group (CG), that is, sows fed conventionally; and an experimental group (EG), that is, sows fed commercial feed plus cacti. Blood glucose in late gestation, and feed intake, milk production and milk quality, development of the piglet, energy balance, post-weaning body weight balance and the interval from weaning to oestrus were recorded. Preprandial blood glucose was $55.9 \mathrm{mg}$ per $\mathrm{dL}$ in EG and 71.4 in CG. Sows on EG had greater daily feed intake and lower negative energy balance $(5.4 \mathrm{~kg} / \mathrm{day}$ and $-2.8 \mathrm{MJ} /$ day $)$ than those on CG $(4.5 \mathrm{~kg} /$ day and -9.4 $\mathrm{MJ} / \mathrm{day})$. Sows fed EG produced more milk (8.6 L/day) than those on CG (8.1 L/day). The quality of milk produced and the weaning weight of piglets were similar for the two groups. Body weight balance after weaning was greater for sows fed EG, 3.5\% versus $-1.5 \%$ in those fed CG. The weaning to oestrus interval was 0.6 days less for sows fed EG than those fed CG. Feeding cactus to lactating sows regulated blood glucose, which improved most of their productive indicators.
\end{abstract}

Keywords: cactus, dietary fibre, energy balance, hypophagia, piglet

\#Corresponding author: rosa_elenap@yahoo.com

\section{Introduction}

Blood glucose concentration regulates appetite (Wynne et al., 2005). During the transition from late pregnancy to lactation, sows experience insulin resistance (Pére \& Etienne, 2007). Physiologically, this causes an increased supply of blood glucose to the pregnant uterus and mammary gland (Thingnes et al., 2012; Bergsma et al., 2009, respectively). This increased energy supply supports the logarithmic growth of foetuses during the last third of gestation (Farmer et al., 2008) and milk production during lactation (Bergsma et al., 2009). However, the increase in blood glucose during the transition period affects the sow negatively by reducing feed intake and thus her consumption of energy (Mosnier et al., 2010). High levels of blood glucose ( $>90 \mathrm{mg} /$ day) around the time of farrowing may facilitate adaptation to the increasing demand for energy (Pére \& Etienne, 2007).

Sows in lactational hypophagia do not meet the demands of energy through feed intake and thus mobilize their body reserves, primarily fat, but in extreme cases also protein (Mosnier et al., 2010). The effects of this mobilization may be greatest in gilts (Mosnier et al., 2010) or in genetically lean sows (OrdazOchoa et al., 2013). Young females have greater nutrient requirements for growth, since they have not reached the size and weight of adults, and have limited body reserves of proteins and fats. The greater demands for growth, in addition to the nutritional demands for synthesis of milk, may compromise their ability to return to oestrus (Chansomboon et al., 2009; Ek-Mex et al., 2015). This mobilization of body tissues can 
delay ovarian reactivation after farrowing, and lengthen the interval from weaning to oestrus (Yoder et al., 2012; Gunn et al., 2014), with downstream effects on subsequent fertility and prolificacy (Rempel et al., 2015).

Lactational hypophagia is most severe during the first week after farrowing (Pére \& Etienne, 2007), However, in conventional lactations (21 days), improved energy balance during the second and third weeks after farrowing may not be sufficient to offset the mobilization of body reserves because of the deficit in feed intake in the first week. This deficit affects milk production and productivity of the gilts or sows negatively (Bergsma et al., 2009). To mitigate the effects of lactational hypophagia, nutritional strategies have been implemented such as increasing the energy density of the diet by incorporating fat (Van der Brand et al., 2000). Likewise, the levels of protein and amino acids have been evaluated to avoid excessive energy loss (Neill \& Williams, 2010). Kim et al. (2009) propose an ideal protein profile, which is a function of the mobilization of body reserves throughout lactation, because this behaviour is dynamic, and varies according to maintenance needs, the development of the mammary gland, and milk production. However, these strategies do not seem to be consistent in affecting the response to feed intake and energy imbalance in lactation. Therefore, nutritional alternatives are required to minimize the mobilization of body reserves and energy imbalance during lactation and to avoid delayed ovarian reactivation after farrowing and its consequences, namely an increase in repeated services, and a decrease in fertility and prolificacy in the next reproductive cycle (Cools et al., 2014).

Quesnel et al. (2009) observed beneficial effects of dietary fibre on feed intake in lactating sows. In sheep, rabbits, and pigs, the dietary fibre of various foods, including cactus (Opuntia spp.), has been linked to improvement in the glucose metabolism, owing to its hypoglycaemic effects and the effect on the synthesis of insulin (Ylönem et al., 2003; Brahim et al., 2012; Onakpoya et al., 2015; Gaitán-Lemus et al., 2018). Thus, ingestion of cactus by lactating sows may regulate blood glucose levels during the first week after farrowing. Feeding cactus can facilitate synthesis of insulin because of its contribution of calcium $\left(\mathrm{Ca}^{2+}\right)$ (Deldique et al., 2013), and provide dietary fibre to modify the absorption of bile salts, cholesterol and glucose (Hsu et al., 2004). All of these effects are anticipated to result in greater feed intake (Quesnel et al., 2009). Therefore, the aim of the current study was to evaluate the effects of dietary inclusion of cactus (Opuntia ficus-indica) on the regulation of blood glucose and productive performance in lactating sows.

\section{Materials and Methods}

This research was conducted at the Swine Production System of Zootechnical Posta of Faculty of Veterinary Medicine Zootechnics of UMSNH, Tarímbaro, Michoacán, Mexico. The animals that were used were bred in accordance with the regulations of the Zootechnical and Animal Health of Mexico for the Humanitarian Care and Use of Animals in Investigation, Secretary of Agriculture and Rural Development. All procedures used in this study conform to the Animal Rights and Protection Act of Ocampo, Michoacán and the Mexican Official Norm for the Production, Care, and Use of Laboratory Animals (NOM-062-ZOO-1999) (Mexico 1999).

Thirty-three hybrid sows (Yorkshire $\mathrm{x}$ Landrace $\mathrm{x}$ Pietrain) that had previously farrowed between one and five times were used in this study. The sows had been served by natural mating with hybrid boars (Yorkshire $x$ Pietrain) 12 hours after presenting oestrus post weaning. At 110 days of gestation they weighed an average of $207 \pm 34 \mathrm{~kg}$. They were housed in groups $(n=7)$ in $16 \mathrm{~m}^{2}$ pens during the first 109 days of gestation. At this stage, sows consumed $2.5 \mathrm{~kg}$ per day of a conventional diet for pregnant sows (Table 1). The experiment was conducted in two time blocks such that 52 farrowing events contributed to the dataset.

According to the experimental design, two groups were formed: a control group (CG), which was fed conventionally; and a treated group (EG), which was fed the commercial feed plus $1.0 \%$ cactus $(O$. ficusindica). There were 26 farrowing events from 15 sows in CG, and 26 farrowing events from 18 sows in EG. For farrowing and lactation, the sows were housed in individual cages with stainless steel bucket feeders and automatic drinking fountains. Lighting and room temperature were controlled artificially, with eight hours of light per day (8:00 to $16: 00$ hours) and an ambient temperature at $20 \pm 1{ }^{\circ} \mathrm{C}$ during the 21 days of lactation. Farrowing was not induced, but it was assisted. Litters were standardized to eight piglets in the first 24 hours after farrowing. Piglets that died during lactation were not replaced. A total of 416 piglets were produced in the investigation. Thirty-one piglets died as a result of crushing $74 \%$ (23 piglets), starvation $12.5 \%$ (4 piglets), diarrhoea $11.5 \%$ (3 piglets), and unknown causes $2.0 \%$ (1 piglet).

During lactation, the sows from the two groups were fed ad libitum with a conventional diet (Table 1). The only variant in the feeding of EG sows was the addition of the cactus (Table 1). The cladodes of $O$. ficus-indica that were offered to the EG sows were approximately 90 days old, and had been cut manually with the required amount $(41.0 \mathrm{~kg})$ each week. The cladodes were fragmented into approximately $3 \times 2 \mathrm{~cm}$ pieces, and were stored at $4{ }^{\circ} \mathrm{C}$ until they were offered to the sows. The quantity that was required for each sow was added at 8:00 hours with the corresponding commercial feed ration. This practice was carried out daily during lactation. 
Table 1 Ingredients and nutrient composition of the conventional diet for gestating sows, and the conventional and experimental diets that were fed to the lactating sows

\begin{tabular}{|c|c|c|c|}
\hline & \multirow[b]{2}{*}{ Gestation diet } & \multicolumn{2}{|c|}{ Lactation diet } \\
\hline & & Control group & Experimental group \\
\hline \multicolumn{4}{|l|}{ Ingredients (g/kg) } \\
\hline Sorghum & 824.0 & 824.0 & 649.5 \\
\hline Soy paste & 60.0 & 60.0 & 100.0 \\
\hline Canola paste & 61.2 & 61.2 & 185.2 \\
\hline Orthophosphate & 11.8 & 11.8 & 5.3 \\
\hline Calcium carbonate & 14.0 & 14.0 & 12.4 \\
\hline Soy oil & 22.0 & 22.0 & 38.5 \\
\hline Lysine & 1.2 & 1.2 & 2.5 \\
\hline Methionine + cysteine & 0.9 & 0.9 & 1.5 \\
\hline Salt & 3.0 & 3.0 & 3.0 \\
\hline Vitamin and mineral premix ${ }^{\mathrm{a}}$ & 2.0 & 2.0 & 2.5 \\
\hline \multicolumn{4}{|l|}{ Nutrient composition ${ }^{b}$} \\
\hline Metabolizable energy (MJ/kg) & 9.6 & 9.6 & 9.6 \\
\hline Crude protein (\%) & 12.5 & 17.5 & 17.3 \\
\hline Crude fat (\%) & 3.7 & 4.5 & 4.4 \\
\hline Fibre (\%) & 3.1 & 4.3 & 4.7 \\
\hline Moisture content (\%) & 12.0 & 12.0 & 13.8 \\
\hline Ash (\%) & 10.0 & 10.0 & 12.9 \\
\hline Nitrogen-free elements (\%) & 41.3 & 48.3 & 54.2 \\
\hline Calcium (\%) & 0.75 & 0.75 & 0.76 \\
\hline Phosphorus (\%) & 0.60 & 0.60 & 0.59 \\
\hline Lysine (\%) & 0.52 & 0.95 & 0.94 \\
\hline Methionine + cysteine (\%) & 0.43 & 0.59 & 0.59 \\
\hline \multicolumn{4}{|c|}{ Nutrient composition for cactus (Opuntia ficus-indica) } \\
\hline Crude protein (\%) & & & 5.6 \\
\hline Crude fat (\%) & & & 0.2 \\
\hline Fibre (\%) & & & 28.8 \\
\hline Moisture content $\%$ & & & 88.6 \\
\hline Ash (\%) & & & 24.5 \\
\hline Nitrogen-free elements (\%) & & & 40.8 \\
\hline Mucilage (g $300 \mathrm{~g}^{-1} \mathrm{dry}$ base) & & & 2.6 \\
\hline
\end{tabular}

${ }^{a}$ Cu: 30 mg; Fe: 160 mg; Zn: 160 mg; Mn: 55 mg; Se: 0.5 mg; Cr: 0.2 mg; vitamin A: 14200 IU; vitamin $D_{3}: 2800$ IU; vitamin $\mathrm{E}: 125 \mathrm{mg}$; vitamin $\mathrm{K}_{3}: 5 \mathrm{mg}$; vitamin $\mathrm{B}_{1}: 2.4 \mathrm{mg}$; vitamin $\mathrm{B}_{2}: 8.7 \mathrm{mg}$; vitamin $\mathrm{B}_{6}: 4.5 \mathrm{mg}$; vitamin $\mathrm{B}_{12}: 0.05 \mathrm{mg}$; pantothenic acid: $35 \mathrm{mg}$; folic acid: $6 \mathrm{mg}$

${ }^{b}$ To determine the nutritional composition of the diet with the addition of $1 \%$ spineless cactus to the feed sample prior to bromatological analysis

Blood glucose and the productive performance of sows during lactation were evaluated. Blood glucose was determined with a glucometer for human use according to methodology described by Perez et al. (2016). Blood samples were drawn on days 85, 100, and 110 of gestation at $08 \mathrm{~h} 00$ (before feeding) and 08h30 (after feeding) by puncturing the right atrial vein. Blood samples were also drawn from each sow on days $1,3,7,10,14,17$, and 21 of lactation.

To determine the productivity of sows during lactation, daily feed intake (DFI) and total feed intake (TFI) were recorded. The feed supplied and rejected by each sow was weighed daily with a digital scale with a $40 \mathrm{~kg}$ capacity and an accuracy of $\pm 0.5 \mathrm{~g}$. Rejected feed was weighed before feeding each morning.

The milk production of sows was estimated according to Sinclair et al. (1999). Briefly, this method consists of a weigh-suckle-weigh sequence for each piglet on days 2, 5, 7, 10, 15, 19, and 21 of lactation. Weighing before and after suckling was done with a digital scale. The procedure was done four 
times on each established day. In addition, suckling time and intervals between measurements were recorded to determine the daily milk producation. To evaluate milk quality, $10 \mathrm{~mL}$ milk was collected from each sow on days 3, 11 and 17 of lactation. The milk was collected manually after an intramuscular injection of $2 \mathrm{~mL}$ oxytocin ${ }^{\circledR}$ intramuscularly. Five minutes after the injection, the udder was massaged, and the milking was performed. Each sample was placed in a sterile container (100 mL capacity) and stored at $4{ }^{\circ} \mathrm{C}$ for further analysis (1 hour post milking) using Lactoscan ${ }^{\circledR}$ equipment (Milkotronic Ltd., Nova Zagora, Bulgaria), which determined the content of lactose, protein and fat.

Piglets were weighed at birth and on days 7, 14, and 21 (weaning) of lactation. Energy balance (EB) was determined, using the methodology that was described by Noblet et al. (1990). The change in weight of the sows from farrowing to weaning (BWP) was determined as the difference between their live weight at day 110 of gestation (SW110) and their weight at weaning (SWW) using a fixed electronic scale (capacity 1$1500 \mathrm{~kg})$. The BWP was also expressed in relative terms as:

$$
\text { BWP } \%=100-\left(\frac{\mathrm{SWW} * 100}{\mathrm{WSPF}}\right)
$$

where WSPF is the weight of the sow after farrowing, which was estimated as:

$$
\text { WSPF }, \mathrm{kg}=\mathrm{SW} 110-\left(\sum \text { birth weights of piglets }+ \text { weight of the placenta }\right)
$$

Lastly, the interval from weaning to oestrus (WEI) was recorded as the difference (in days) between the dates that the piglets were weaned and when the sow was displayed signs of oestrus.

The data were analysed using SAS (SAS Institute, Cary, NC, USA). For all dependent variables, their residuals, after analysis as originally recorded, were tested for normality using the Shapiro-Wilks test and for homogeneity of variance using Bartlett's test. If a dependent variable was not distributed normally, it was log-transformed prior to the final analysis to normalize its distribution. Using PROC MIXED, BG, DFI, EB, weights of the piglets and MQ were analysed with a model that was appropriate for repeated measurements (Littell et al., 1998). Sows within treatment modelled as a random effect, and treatment, parity, time (weeks of lactation) and the treatment $x$ time interaction were modelled as fixed effects. The TFI, BWP, and WEI were modelled as functions of treatment, parity and the treatment $x$ parity interaction as fixed effects. Hypotheses were declared significant with $\alpha=0.05$. Pearson's correlation coefficients between milk production, fat in milk and weight of the piglets were calculated during the three weeks of lactation. The values in text, tables and figures are presented as least squares mean \pm standard deviation (SD).

Lactation curves were calculated using the non-linear incomplete gamma function of Wood (1967):

$$
Y_{n}=a n^{b} e^{-c n}
$$

where: $Y_{n}=$ milk production on the $n^{\text {-th }}$ day of lactation

$e=$ base of natural logarithm (In)

$a, b$, and $c=$ parameters to be estimated: $a=a$ factor of scale for milk production at the beginning of lactation; while $b$ and $c$ define the slope of the curve before and after the peak of lactation.

The data were transformed to natural logarithms such that the Wood's equation was linearized as:

$$
\text { In } Y_{n}=\operatorname{Ina}+b \operatorname{In} n-c n
$$

After this transformation, the parameters $(a, b$ and $c$ ) were estimated by multiple regression. Based on these estimates the time of maximum milk production $\left(t_{\max }\right)$ and the maximum milk production $\left(\mathrm{MP}_{\max }\right)$ were calculated for each treatment as:

$$
\mathrm{t}_{\max }=\mathrm{b} / \mathrm{c} \text {, and } \mathrm{MP}_{\max }=\mathrm{a}(\mathrm{b} / \mathrm{c})^{\mathrm{b}} \mathrm{e}^{-\mathrm{b}} \text {, respectively. }
$$

\section{Results and Discussion}

During late gestation, feed intake was similar for the treated and control groups (Table 2). Without considering the consumption of cactus, DFI of the sows in EG was greater $(P<0.01)$ than for the sows in CG throughout lactation. Feed intake of the sows in EG was not affected $(P=0.63)$ by parity. However, sows in EG that had multiple parities did consume more cactus compared with sows in CG; and for sows fed CG the first-parity sows consumed less feed compared with sows that had multiple parities (Table 2). Because the length of lactation was fixed (21 days), the results pertaining to TFI were similar. 
Table 2 Means ( \pm SE) for consumption of feed and cactus (Opuntia ficus-indica) by sows fed either a control diet or provided with cactus as a supplement ${ }^{1}$

\begin{tabular}{lcccccc}
\hline & \multicolumn{2}{c}{ Daily feed intake } & \multicolumn{2}{c}{ Total feed intake } & \multicolumn{2}{c}{ Daily intake Total intake } \\
\cline { 2 - 6 } & CG & EG & CG & EG & \multicolumn{2}{c}{ EG } \\
\hline $\begin{array}{l}\text { Gestation } \\
\quad \text { Day 85 to 114 }\end{array}$ & $2.5 \pm 0.1$ & $2.5 \pm 0.1$ & $76.2 \pm 0.4$ & $76.7 \pm 0.4$ & -- & -- \\
Lactation & & & & & & \\
$\quad$ Days 1 to 7 & $3.8 \pm 0.3$ & $4.4 \pm 0.3$ & $27.0 \pm 1.2$ & $31.2 \pm 1.4$ & $1.7 \pm 0.1$ & $9.8 \pm 1.1$ \\
$\quad$ Days 8 to14 & $5.4 \pm 0.3$ & $6.2 \pm 0.4$ & $35.8 \pm 1.2$ & $40.6 \pm 1.4$ & $1.6 \pm 0.1$ & $10.0 \pm 0.9$ \\
Days 15 to 21 & $5.1 \pm 0.3$ & $6.0 \pm 0.3$ & $33.6 \pm 1.0$ & $37.1 \pm 1.5$ & $1.5 \pm 0.1$ & $8.4 \pm 1.1$ \\
Days 1 to 21 & $4.5 \pm 0.3$ & $5.4 \pm 0.3$ & $95.3 \pm 1.8$ & $109.1 \pm 3.6$ & $1.7 \pm 0.1$ & $33.0 \pm 1.9$ \\
Parity & & & & & & \\
1st & $4.1 \pm 0.3$ & $5.2 \pm 0.3$ & $90.7 \pm 2.2$ & $112 \pm 5.3$ & $1.3 \pm 0.1$ & $26 \pm 1.4$ \\
2nd & $4.7 \pm 0.3$ & $5.5 \pm 0.3$ & $98.5 \pm 2.0$ & $116 \pm 2.6$ & $1.7 \pm 0.1$ & $34 \pm 1.8$ \\
3rd to 5th & $4.6 \pm 0.3$ & $5.7 \pm 0.3$ & $96.4 \pm 2.4$ & $119 \pm 3.4$ & $1.8 \pm 0.1$ & $36 \pm 1.2$ \\
\end{tabular}

${ }^{1}$ CG unsupplemented control group, EG: group supplemented with cactus

The estimated energy requirements of the sows increased as lactation progressed (Table 3). At 24 hours after farrowing, the estimated energy requirements were $39.3 \mathrm{MJ}$ per sow and $37.0 \mathrm{MJ}$ per sow ( $P$ $=0.19$ ) for the sows in the CG and EG, respectively. Over the entire lactation, sows in the CG had an 11.7 MJ per day greater $(P=0.01)$ energy deficit than those in that were supplemented with cactus (Table 3$)$. For sows that were fed the control diet, the energy deficit became greater from the first to the second week of lactation (Table 3). In the sows that consumed EG, the opposite effect was found, with the change in energy balance being positive. For the sows in CG, those in their 3rd to 5th parities had a greater energy deficit than those in earlier parities (Table 3).

During the last third of gestation, the sows that were ultimately assigned to each dietary treatment group had similar $(P>0.05)$ concentrations of blood glucose both before $(66.7 \mathrm{mg}$ per $\mathrm{dL})$ and after feeding (74.3 $\mathrm{mg}$ per $\mathrm{dL}$ ). However, during lactation blood glucose concentration before and after feeding was consistently greater in CG than in EG (Table 4). For sows in EG, their post-prandial blood glucose levels held approximately constant (63.4 to $64.6 \mathrm{mg}$ pre $\mathrm{dL}$ ) throughout the three weeks of lactation, whereas their preprandial blood glucose levels were somewhat lower during the second week of lactation than in the first and third weeks.

The physiological hypophagia that occurs in sows during lactation is established immediately after farrowing as a consequence of a high concentration of blood glucose from day 85 of gestation (Pére \& Etienne, 2007; Mosnier et al., 2010). Before farrowing, the physiological objective is to provide energy to the foetuses for their growth during the last third of gestation (Farmer et al., 2008). After farrowing, high concentrations of blood glucose are maintained to supply energy requirements for synthesis and milk production during lactation (Bergsma et al., 2009). However, the elevated levels of blood glucose affect the centres of the hypothalamus, which regulates the appetite and satiety of post-farrowing sows (Pére \& Etienne, 2007). Here, this effect seemed to be diminished as the sows in CG had greater pre- and postprandial concentrations of blood glucose than the sows that were offered cactus. Likewise, the sows of CG had reduced voluntary feed intake during the three weeks of lactation compared with EG sows.

It has been established (Pere \& Etienne, 2007; Mosnier et al., 2010; Yoder et al., 2012) that physiological hypophagia has detrimental effects on primiparous sows ( $<3$ parities) and on genetically lean sows (Ordaz-Ochoa et al., 2013). Feed intake in lactation is regulated mainly by the endocrine and metabolic changes that affect the sows immediately after farrowing and during lactation. These effects are accentuated in younger sows, which have greater nutrient requirements for growth and limited body energy reserves (Mosnier et al., 2010). 
Table 3 Means $( \pm$ SE) for time during lactation and parity on the energy balance (MJ per day) of lactating sows whose diet was supplemented with cactus or of sows in an unsupplemented control group ${ }^{1}$

\begin{tabular}{|c|c|c|c|c|c|c|}
\hline & \multicolumn{2}{|c|}{ Estimated energy intake } & \multicolumn{2}{|c|}{ Estimated energy requirement } & \multicolumn{2}{|c|}{ Energy balance } \\
\hline & CG & EG & CG & EG & CG & EG \\
\hline \multicolumn{7}{|l|}{ Day of lactation } \\
\hline Day 1 to 7 & $40.1 \pm 1.7$ & $48.0 \pm 1.9$ & $47.6 \pm 1.8$ & $46.0 \pm 2.3$ & $-7.5 \pm 2.1$ & $-1.9 \pm 3.2$ \\
\hline Day 8 to 14 & $49.2 \pm 1.6$ & $60.2 \pm 1.5$ & $55.2 \pm 2.6$ & $57.1 \pm 2.4$ & $-6.1 \pm 3.7$ & $3.5 \pm 2.6$ \\
\hline Day 15 to 21 & $44.6 \pm 1.8$ & $53.6 \pm 2.3$ & $59.6 \pm 3.7$ & $60.1 \pm 3.5$ & $-15.0 \pm 2.3$ & $-6.9 \pm 3.6$ \\
\hline General mean & $44.6 \pm 1.8$ & $53.9 \pm 1.7$ & $59.1 \pm 3.5$ & $56.7 \pm 3.0$ & $-14.5 \pm 2.6$ & $-2.8 \pm 2.9$ \\
\hline \multicolumn{7}{|l|}{ Parity } \\
\hline $1 \mathrm{st}$ & $40.1 \pm 2.3$ & $55.4 \pm 3.3$ & $51.9 \pm 2.5$ & $57.1 \pm 3.2$ & $-9.1 \pm 2.7$ & $-2.1 \pm 3.5$ \\
\hline 2nd & $45.8 \pm 2.8$ & $53.3 \pm 2.7$ & $53.0 \pm 3.6$ & $56.8 \pm 3.4$ & $-8.3 \pm 3.6$ & $-3.6 \pm 3.7$ \\
\hline 3 rd to 5 th & $45.5 \pm 2.9$ & $56.2 \pm 2.9$ & $62.5 \pm 2.7$ & $60.6 \pm 3.8$ & $-10.8 \pm 3.2$ & $-2.8 \pm 3.1$ \\
\hline
\end{tabular}

${ }^{1}$ CG unsupplemented control group, EG: group supplemented with cactus

Table 4 Means $( \pm$ SE) for time during lactation and parity of pre- and post-prandial blood glucose levels (mg per $\mathrm{dL}$ ) of lactating sows whose diet was supplemented with cactus or of sows in an unsupplemented control group $^{1}$

\begin{tabular}{lcccc}
\hline & \multicolumn{2}{c}{ Pre-prandial } & \multicolumn{2}{c}{ Post-prandial } \\
\cline { 2 - 5 } & CG & EG & CG \\
\hline Day of lactation & & & \\
$\quad$ Day 1 to 7 & $68.1 \pm 2.3$ & $60.6 \pm 1.4$ & $79.5 \pm 2.4$ & $64.6 \pm 2.2$ \\
Day 8 to 14 & $69.2 \pm 2.2$ & $53.8 \pm 1.7$ & $81.1 \pm 2.8$ & $63.4 \pm 1.9$ \\
Day 15 to 21 & $68.8 \pm 1.8$ & $58.0 \pm 1.9$ & $77.6 \pm 2.5$ & $63.9 \pm 2.0$ \\
General mean & $68.4 \pm 1.5$ & $55.9 \pm 1.7$ & $82.0 \pm 2.1$ & $62.5 \pm 1.9$ \\
Parity & & & & \\
1st & $74.5 \pm 1.1$ & $58.4 \pm 1.5$ & $83.7 \pm 1.9$ & $69.9 \pm 1.9$ \\
2nd & $67.6 \pm 2.3$ & $55.3 \pm 1.7$ & $78.6 \pm 2.7$ & $61.5 \pm 1.7$ \\
3rd to 5th & $65.5 \pm 2.3$ & $59.2 \pm 1.8$ & $76.8 \pm 2.5$ & $62.6 \pm 2.0$ \\
1. & & &
\end{tabular}

${ }^{1}$ CG unsupplemented control group, EG: group supplemented with cactus

Therefore, the present results, which showed lower pre- and post-prandial concentrations of blood glucose and increased DFI, which were observed specifically in EG, suggest that it is possible to manipulate the effect of blood glucose to control the appetite in sows after farrowing and during lactation through dietary supplementation with cactus (O. ficus-indica). This is supported by evidence that Opuntia spp has hypoglycaemic properties (Alarcón-Aguilar et al., 2003), as has been reported in human beings (Onakpoya et al., 2015) and in various species of animals (Brahim et al., 2012; Halmi et al., 2013; Gaitán-Lemus et al., 2018).

The mechanism by which cactus intake causes a reduction of blood glucose concentration is not known precisely. However, among the possible explanations, it has been found that the pectin and mucilage of cactus slow the transit of feed through the gastrointestinal tract and increase glucose absorption (Onakpoya et al., 2015). Nuñez-Lopez et al. (2013) suggested that the non-fermentable dietary fibre of cactus promotes an increase in the release of glucagon-like peptide-1 (GLP-1), inhibiting the release of glucagon and, consequently, decreasing glucose synthesis. In addition, GLP-1 causes an increase in insulin synthesis (Alarcón et al., 2003). Calcium may also be involved in the regulation of blood glucose, since calcium is essential for insulin secretion (Pari \& Latha, 2005; Newsholme et al., 2005). The $\mathrm{Ca}^{2+}$ in O. ficus-indica (0.59 mg 100 per g) (Pinos-Rodríguez et al., 2010) has high bioactivity (Contreras-Padilla et al., 2015). It stimulates $\beta$-pancreatic cells, provoking a reduction in blood glucose through i) oxidative decarboxylation; ii) allosteric capacity to activate glutamate dehydrogenase; and iii) transamination of $\alpha$-ketoisocaprote (Halmi et 
al., 2013). This subsequently increases the flow of the tricarboxilic acid and the ATP/ADP reaction, the effect of which is reflected in closing potassium-ATP channels and depolymerizing the plasmatic membrane, allowing channels of $\mathrm{Ca}^{2+}$ to open and then facilitating the secretion of insulin (Newsholme et al., 2005). The reduction of blood glucose concentration in lactating sows, owing to the effect of cactus intake, lessens hypophagia during lactation, which was observed in EG sows. The concentrated feed intake (31-40 kg on dry basis per sow per week) plus cactus (8-10 kg fresh basis per sow per week) established that lactating sows have the gastric capacity to consume greater quantities of feed than they do (30.9 kg per sow per week (Sánchez et al., 2015) to $34.4 \mathrm{~kg}$ per sow per week (Cools et al., 2014) during lactation.

Increased feed intake of sows may favour the increases in the amount and quality of the milk. It was found that $E G$ sows produced more $(P=0.0218)$ milk on average and in total during lactation compared with CG sows (Table 5). Estimates of the parameters of the incomplete gamma function that was used to summarize these milk production data are shown in Table 6. Initial milk production was $2.6 \mathrm{~L}$ per sow for CG and $2.7 \mathrm{~L}$ per sow for EG, with peak production of 9.6 and $10.3 \mathrm{~L}$ per sow occurring on days 15.2 and 14.9 for CG and EG, respectively, and day 21 milk production of 8.2 and 8.8 L per sow for CG and EG, respectively.

Table 5 Means ( \pm SE) for average daily and cumulative milk production $(L)$ of lactating sows whose diet was supplemented with cactus or of sows in an unsupplemented control group ${ }^{1}$

\begin{tabular}{lcccc}
\hline \multirow{2}{*}{ Day of lactation } & \multicolumn{2}{c}{ CG } & \multicolumn{2}{c}{ EG } \\
\cline { 2 - 5 } & Daily & Cumulative & Cumulative \\
\hline 1 to 7 & $5.7 \pm 0.4$ & $39.8 \pm 0.4$ & $6.0 \pm 0.4$ & $42.2 \pm 0.4$ \\
8 to 14 & $9.1 \pm 0.1$ & $63.7 \pm 0.8$ & $9.8 \pm 0.2$ & $68.4 \pm 0.9$ \\
15 to 21 & $9.5 \pm 0.1$ & $66.5 \pm 1.0$ & $10.1 \pm 0.2$ & $71.0 \pm 1.0$ \\
General mean & $8.1 \pm 0.4$ & $169.9 \pm 2.2$ & $8.6 \pm 0.5$ & $181.6 \pm 2.3$ \\
\hline
\end{tabular}

${ }^{1}$ CG unsupplemented control group, EG: group supplemented with cactus

Table 6 Incomplete gamma functions describing the lactation curves for sows whose diet was supplemented with cactus and for sows in an unsupplemented control group ${ }^{1}$

\begin{tabular}{lcccccc}
\hline Group & Equation & PPT, days & PP, kg & TPE, kg & SCE & $\mathrm{R}^{2}$ \\
\hline CG & $\mathrm{Y}=2.6030 \mathrm{X}^{0.7435} \mathrm{e}^{-0.0488 \mathrm{X}}$ & 15.23 & $9.57^{\mathrm{a}}$ & $169.6^{\mathrm{a}}$ & $0.0045^{\mathrm{a}}$ & 0.98 \\
EG & $\mathrm{Y}=2.66584 \mathrm{X}^{0.7799} \mathrm{e}^{-00520 \mathrm{X}}$ & 14.99 & $10.26^{\mathrm{b}}$ & $181.2^{\mathrm{b}}$ & $0.0021^{\mathrm{b}}$ & 0.99
\end{tabular}

${ }^{1}$ CG unsupplemented control group, EG: group supplemented with cactus

PPT: peak production time; PP: production at peak; PTE: total production estimate; SCE: sum of squares of error; $\mathrm{R}^{2}$ : determination coefficient

${ }_{a, b}$ Within columns, different superscripts indicate statistical difference $(P<0.05)$ (Wood 1967)

It is recognized that changes in the diet of lactating sows may affect their consumption and consequently the production and quality of milk (Hurley, 2015). Above all, an input (such as cactus) can alter the metabolic processes of synthesis and production of milk and cause a lower performance in the development of lactating piglets owing to the low content of protein and energy contained in cactus. Lee et al. (2014) reported that sows produced $8.5 \mathrm{~kg}$ of milk per day or $178.5 \mathrm{~L}$ per lactation. This was a larger quantity of milk than was produced by the CG sows, but was similar to that observed in EG. However, these differences among studies in milk production are possibly attributable to differences in the genetic material and the environment (Farmer et al., 2008). In contrast, Thingnes et al. (2012) suggested that additional feed intake by the sows during lactation is not reflected in milk production, but is used to reduce weight loss.

Chen et al. (2014) observed that non-starch polysaccharides in cactus increased the viscosity of the food bolus, reduced gastric emptying, and generated greater absorption of nutrients in the bolus. Chen et al. (2014) also evaluated the inclusion of fibre (peas) in the diet of pigs, and noted that this increased the expression level of the GLP-1 gene. This protein is related to the renewal of the intestinal epithelial cells and, in turn, to greater efficiency in the absorption of nutrients from food (Brahim et al., 2012). Fermentation of non-starch polysaccharides in pig colons also increases the production of volatile fatty acids (Chen et al., 2014) and consequently greater energy can be channelled to metabolic processes (Brahim et al., 
2012), such as milk production. When sows do not consume sufficient dietary energy, body reserves are mobilized to meet their requirements (Thingnes et al., 2012). In addition to their greater intake of dietary energy in the form of non-structural carbohydrates in cactus, the need for mobilization of body reserves may be reduced for sows that are fed cactus. More energy is available to them because of greater efficiency in the absorption of nutrients (Gebremarian et al., 2006) and/or an increase in volatile fatty acids (Chen et al., 2014). This higher synthesis of volatile fatty acids in sows that consumed cactus may best explain their positive energy balance during lactation. Why this effect was manifest only in second parity sows is inexplicable.

The average quality of the milk, as assessed from its lactose, protein and fat contents, did not differ between the sows fed cactus and those in the unsupplemented control group $(P>0.05)$. The nutritional content of the sows' milk was reduced as the days in milk increased $(P<0.05)$. Even with the concurrent increase in the amount of milk produced, the total lactose, protein and fat consumed by the nursing piglets was reduced by the third week of lactation.

Table 7 Means $( \pm$ SE) for nutrient content of milk from sows whose diet was supplemented with cactus or sows in an unsupplemented control group ${ }^{1}$ on days 3,11 and 17 of lactation

\begin{tabular}{|c|c|c|c|c|c|c|}
\hline \multirow{2}{*}{ Day } & \multicolumn{3}{|c|}{ CG } & \multicolumn{3}{|c|}{ EG } \\
\hline & Lactose & Protein & Fat & Lactose & Protein & Fat \\
\hline 3 & $7.1 \pm 0.1$ & $5.0 \pm 0.1$ & $11.4 \pm 0.6$ & $7.3 \pm 0.2$ & $5.1 \pm 0.1$ & $10.3 \pm 0.5$ \\
\hline 11 & $6.6 \pm 0.1$ & $4.5 \pm 0.1$ & $7.9 \pm 0.3$ & $6.8 \pm 0.2$ & $4.6 \pm 0.1$ & $7.0 \pm 0.2$ \\
\hline 17 & $6.1 \pm 0.1$ & $4.0 \pm 0.1$ & $5.6 \pm 0.2$ & $5.8 \pm 0.1$ & $3.8 \pm 0.1$ & $4.8 \pm 0.3$ \\
\hline
\end{tabular}

${ }^{1}$ CG unsupplemented control group, EG: group supplemented with cactus

The growth of the piglets during lactation was affected $(P<0.05)$ by the interaction of treatment and parity (Table 8). Piglets from second parity sows that were fed cactus were heavier from day 7 of lactation onwards than any other group of piglets that were similar in weight to each other.

The interaction of treatment and parity was highly significant at all times that weight was recorded (Table 8). Sows in CG lost weight during lactation, whereas those in EG gained weight (Table 8). Second parity sows in CG lost least weight during lactation, and second parity sows in the EG gained most weight, relative to either 1st or 3rd to 5th parity sows that were fed similarly. Sows in their 1st or 2nd parities that were fed cactus had shorter WEls than sows of similar ages in CG (Table 8). Older sows did not differ in WEI, irrespective of their diet.

In addition to reducing blood glucose concentration, consumption of cactus may improve the digestive processes of lactating sows. The present results verify the greater weight gain that was observed in animals fed with diets complemented with cactus (Brahim et al., 2012). It is suggested that this increase was because of the high (53.9\%) content of soluble carbohydrates (Gebremarian et al., 2006). In this research, the diet with cactus contained a higher percentage of carbohydrates (54.2\% versus $48.3 \%$ ), which favoured an increase in feed intake. During lactation, greater feed intake may reduce weight loss or, as for the sows in EG, even allow for some gain, which may trigger earlier ovarian reactivation and would result in a reduced WEI (Table 8). This reduction is associated with greater consumption of energy, the result of which can be a positive effect on ovarian follicular dynamics (Viñoles et al., 2008). 
Table 8 Means ( \pm SE) for weight and weight balance sows during lactation, weights of their piglets, and interval from weaning to oestrus as affected by feeding of cactus ${ }^{1}$ and parity

\begin{tabular}{lcccccc}
\hline & \multicolumn{2}{c}{ 1st parity } & \multicolumn{2}{c}{ 2nd parity } & \multicolumn{2}{c}{ 3rd to 5th parity } \\
\cline { 2 - 7 } Indicator $^{2}$ & CG & EG & CG & EG & CG & EG \\
\hline Weight of sow, $k g$ & & & & & & \\
Day 110 gestation & $175.7 \pm 2.9$ & $193.1 \pm 5.3$ & $201.4 \pm 3.9$ & $199.0 \pm 4.5$ & $239.5 \pm 2.3$ & $215.0 \pm 5.7$ \\
Day 1 lactation & $151.3 \pm 3.1$ & $174.2 \pm 3.8$ & $178.0 \pm 4.6$ & $172.6 \pm 2.6$ & $220.0 \pm 2.6$ & $200.3 \pm 4.6$ \\
Day 21 lactation & $142.0 \pm 2.7$ & $181.1 \pm 2.4$ & $175.7 \pm 2.2$ & $191.8 \pm 4.4$ & $199.4 \pm 3.6$ & $214.1 \pm 3.1$ \\
BWP, kg & $-9.3 \pm 1.7$ & $+6.9 \pm 1.0$ & $-2.3 \pm 0.6$ & $+19.2 \pm 1.7$ & $-20.6 \pm 2.0$ & $+13.8 \pm 1.7$ \\
BWP, \% & $-6.2 \pm 0.8$ & $+3.9 \pm 0.7$ & $-1.3 \pm 0.7$ & $+11.2 \pm 0.3$ & $-9.4 \pm 1.2$ & $+6.9 \pm 0.9$ \\
Weight gain of piglets during lactation, $g$ & & & & $178.8 \pm 7.5$ & $161.1 \pm 3.9$ & $169.7 \pm 11.2$ \\
Day 1 to 7 & $168.6 \pm 7.1$ & $166.4 \pm 6.8$ & $182.3 \pm 3.2$ & 17.9 & $216.8 \pm 5.5$ \\
Day 8 to 14 & $218.0 \pm 10.6$ & $194.6 \pm 2.6$ & $197.5 \pm 4.7$ & $236.5 \pm 6.4$ & $206.1 \pm 6.5$ & 24.5 \\
Day 15 to 21 & $267.4 \pm 95.6$ & $222.9 \pm 4.0$ & $212.7 \pm 9.6$ & $294.7 \pm 9.2$ & $249.6 \pm 10.7$ & $264.0 \pm 8.2$ \\
General means & $217.5 \pm 18.7$ & $195.4 \pm 4.6$ & $198.0 \pm 6.2$ & $235.8 \pm 8.5$ & $207.2 \pm 8.8$ & $217.0 \pm 8.0$ \\
WPW, kg & $5.7 \pm 0.1$ & $5.5 \pm 0.1$ & $5.4 \pm 0.1$ & $5.8 \pm 0.2$ & $5.2 \pm 0.1$ & $5.4 \pm 0.1$ \\
WEl, days & $6.6 \pm 0.3$ & $5.2 \pm 0.2$ & $6.0 \pm 0.3$ & $5.1 \pm 0.3$ & $5.6 \pm 0.3$ & $5.9 \pm 0.2$ \\
\hline
\end{tabular}

${ }^{1}$ CG unsupplemented control group, EG: group supplemented with cactus

2 BWP: difference in body weight from between day 1 and day 21 of lactation; WPW: average weight of piglet at weaning; WEI: interval from weaning to oestrus

To minimize the loss of body weight during lactation and to ensure that the WEI was not affected, Noble et al. (1990) indicated that the energy balance during lactation must be $-8.5 \mathrm{MJ}$ per day. This is a greater energy deficit than was found in this research for sows that consumed cactus and had an average energy balance of $-2.8 \mathrm{MJ}$ per day, as opposed to CG sows whose energy balance was $-14.5 \mathrm{MJ}$ per day. The results are approximately parallel with those for DFI, in which the energy intake of the sows of EG was 9.3 MJ per day greater than CG (Table 3).

\section{Conclusions}

The addition of fresh cactus ( $O$. ficus-indica) to the diet of lactating sows causes greater voluntary feed intake from its hypoglycaemic effect and increases the synthesis of milk without affecting its nutritional quality, ensuring normal development of piglets during lactation. These improvements are achieved without decreasing the body reserves of sows during lactation, which contributes to a better reproductive performance once lactation is over. Implementation of this technology may be challenging, because feeding fresh cactus can be difficult in intensive systems of swine production. However, this technology may be beneficial to farmers who manage less industrialized systems of swine production. More research should be carried out to develop new technologies for processing cactus in order to facilitate its use as a dietary supplement.

\section{Acknowledgements}

The authors thank the Facultad de Medicina Veterinaria y Zootecnia-UMSNH for supporting this research. They also thank CONACYT for the funding provided.

\section{Authors' Contributions}

RO, REP, and GO conceived and designed the experiments. RO, REP, and GO performed the analyses. All authors wrote the manuscript, reviewed its contents, and approved the final version of the manuscript.

\section{Conflict of Interest Declaration}

None of the authors of this research paper or the authors' institutions has a financial or other relationship with other people or organizations that may have had an inappropriate influence on this work. 


\section{References}

Alarcón-Aguilar, F.J., Valdes-Arzate, A., Xolalpa-Molina, S., Banderas-Dorantes T., Jimenez-Estrada, M., HernandezGalicia, E. \& Roman-Ramos, R. 2003. Hypoglycemic activity of two polysaccharides isolated from Opuntia ficusindica and Opuntia streptacantha. Proc. West Pharm. Soc. 46, $139-42$. https://www.ncbi.nlm.nih.gov/pubmed/14699912.

Bergsma, R., Kanis, E., Verstegen, M.W.A., Van der Peet-Schwering, C.M.C. \& Knol, E.F., 2009. Lactation efficiency as a result of body composition dynamics and feed intake in sows. Livest. Sci. 125, $208-22$. https://doi.org/10.1016/j.livsci.2009.04.011.

Brahim, K.L., Abdelkader, D., Miloud, H. \& Kheira, G., 2012. Effect of incorporation of the spineless Opuntia ficus Indica in diets on biochemical parameters and its impact on the average weight of ewes during the maintenance. Global Vet. 8, 352-59.

Chansomboon, C., Elzo, M.A., Suwanasopee, T. \& Koonawootrittriron, S., 2009. Genetic and environmental factors affecting weaning-to-first service interval in a Landrace-Large White swine population in Northern Thailand Kasetsart. J. Nat. Sci. 43, 669-679.

Chen, X.B., Mao, L.Q., Che, B., Yu, J., He, J., Yu, G.Q., Han, Z.Q., Huang, P., Zheng, D. \& Chen, W., 2014. Impact of fibre types on gut microbiota, gut environment and gut function in fattening pigs. Anim. Feed Sci. Technol. 195, 101-11. https://doi.org/10.1016/j.anifeedsci.2014.06.002.

Contreras-Padilla, M., Rivera-Muñoz, E.M., Gutiérrez-Cortez, E., del López, A.R. \& Rodríguez-García, M.E., 2015. Characterization of crystalline structures in Opuntia ficus-indica. J. Biol. Phys. 41, 99-112. https://doi.org/10.1007/s10867-014-9368-6.

Cools, A., Maesb, D., Decaluwéa, R., Buysec, J., Kempend, T.A.G.T., Liesegange, A. \& Janssens, G.P.J., 2014. Ad libitum feeding during the peripartal period affects body condition, reproduction results and metabolism of sows. Anim. Feed Sci. Technol. 145, 130-40. https://doi.org/10.1016/j.anireprosci.2014.01.008.

Deldicque, L., Van Proeyen, K., Ramaekers, M., Pischel, I., Sievers, H. \& Hespel, P., 2013. Additive insulinogenic action of Opuntia ficus-indica cladode and fruit skin extract and leucine after exercise in healthy males. J. Int. Soc. Sports. Nutrition 10, 1-6.

Ek-Mex, J.E., Segura-Correa, J.C., Alzina-López, A. \& Batista-Garcia, L., 2015. Lifetime and per year productivity of sows in four pig farms in the tropics of Mexico. Trop. Anim. Health Prod. 47, 503-509. https://doi.org/10.1007/s11250-014-0749-4.

Farmer, C., Trottier, N. \& Dourmad, J.Y., 2008. Review: current knowledge on mammary blood flow, mammary uptake of energy precursors and their effects on sow milk yield. Can. J. Anim. Sci. 88, 195-204. https://doi.org/10.4141/CJAS07074.

Gaitán-Lemus, S.B., Ordaz-Ochoa, G., Val-Arreola, D., Martínez-Flores, H.E., Pérez-Sámchez, R.E. \& Ortiz-Rodríguez, R., 2018. Diet supplemented with nopal (Opuntia ficus-indica L.) modifies productive behaviour and blood profile in pigs, Revista Chapingo Serie Zonas Áridas. XVII(1), 39-50. doi:10.5154/r.rchsza.2017.11.011.

Gebremarian, T., Melaku, S. \& Yau, A., 2006. Effect of different levels of cactus (Opuntia ficus-indica) inclusion on feed intake, digestibility and body weight gain in (Eragrostis tef) straw-based feeding of sheep. Anim. Feed Sci. Technol. 131, 42-51. https://doi.org/10.1016/j.anifeedsci.2006.02.003.

Gunn, P.J., Schoonmaker, J.P., Lemenager, R.P. \& Bridges, G.A., 2014. Feeding excess crude protein to gestating and lactating beef heifers: Impact on parturition, milk composition, ovarian function, reproductive efficiency and preweaning progeny growth. Livest. Sci. 167, 435-48. https://doi.org/10.1016/j.livsci.2014.05.010.

Halmi, B.S., Benlaksira, B., Bechtarzi, K., Berouel, K., Serakta, M., ..., Hamdi Pacha, Y., 2013. Pharmaco-toxicological study of Opuntia ficus indica L. aqueous extract in experimental animals. Int. J. Med. Arom. Plants 3. 375-81.

Hsu, C.K., Liao, J.W., Chung, Y.C., Hsieh, C.P. \& Chan, Y.C., 2004. Xylooligosaccharides and fructooligosaccharides affect the intestinal microbiota and precancerous colonic lesion development in rats. Journal of Nutrition 134 , 1523-1528. https://doi.org/10.1093/jn/134.6.1523.

Hurley, W.L., 2015. The gestating and lactating sow. Chapter 9: Composition of sow colostrum. Wageningen Academic Publishers, Wageningen, The Netherlands.

Kim, S.W., Hurley, W.L., Wu, G. \& Ji, F., 2009. Ideal amino acid balance for sows during gestation and lactation. J. Anim. Sci. 87, E123-E132. doi:10.2527/jas.2008-1452.

Lee, S.H., Joo, Y.K., Lee, J.W., Ha, Y.J., Yeo, J.M. \& Kim, W.Y., 2014. Dietary conjugated linoleic acid (CLA) increases milk yield without losing body weight in lactating sows. J. Anim. Sci. and Technol. 56, 1-9. https://doi.org/10.1186/2055-0391-56-11.

Littell, R.C., Henry, P.R. \& Ammerman, C.B., 1998. Statistical analysis of repeated measures data using SAS procedures. J. Anim. Sci. 76, 1216 -1231. https://doi.org/10.2527/1998.7641216x.

Mexico (Secretaría de Agricultura, Ganadería, Desarrollo Rural, Pesca y Alimentación), 1999. Especificaciones técnicas para la producción, cuidado y uso de animales de laboratorio. Diario Oficial de la Federación 22 de agosto de 2001 Mexico. NOM-062-ZOO-1999. http://www.fmvz.unam.mx/fmvz/principal/archivos/062ZOO.pdf. (In Spanish).

Mosnier, E., Etienne, M., Ramaekers, P. \& Pére, M.C., 2010. The metabolic status during the peri partum period affects the voluntary feed intake and the metabolism of the lactating multiparous sow. Livest. Sci. 127, 127-36. https://doi.org/10.1016/j.livsci.2009.06.023.

Neill, C. \& Williams, N., 2010. Milk production and nutritional requirements of modern sows. London Swine Conference 2010, London, Ontario, Canada, 31 March and 1 April 2010. https://thepigsite.com/articles/milk-production-andnutritional-requirements-of-modern-sows.

Newsholme, P., Brennan, L., Rubi, B. \& Maechler, P., 2005. New insights into amino acid metabolism, beta-cell function and diabetes. Clin. Sci. (Lond). 108, 185-194. 
Noblet, J., Dourmad, J.Y. \& Etienne, M., 1990. Energy utilization in pregnant and lactating sows: modelling of energy requirements. J. Anim. Sci. 68, 562-72. https://doi.org/10.2527/1990.682562x.

Nuñez-Lopez, M.A., Paredes-López, O. \& Reynoso-Camacho, R., 2013. Functional and hypoglycemic properties of nopal cladodes (O. ficus-indica) at different maturity stages using in vitro and in vivo tests. J. Agric. Food Chem. 61, 10981-86. https://doi.org/10.1021/jf403834x.

Onakpoya, I.J., O'Sullivan, J. \& Heneghan, C.J., 2015. The effect of cactus pear (Opuntia ficus-indica) on body weight and cardiovascular risk factors: A systemic review and meta-analysis of randomized clinical trials. Nutrition 31 , 640-46. https://doi.org/10.1016/j.nut.2014.11.015.

Ordaz-Ochoa, G., Juárez-Caratachea, A., García-Valladares, A., Rosa Elena Pérez-Sánchez, R.E. \& Ortiz-Rodríguez, R., 2013. Efecto del número de parto sobre los principales indicadores reproductivos de las cerdas. Rev. Cient. 23, 511-19.

Pari, L. \& Latha, M., 2005. Antidiabetic effect of Scoparia dulcis: Effect on lipid peroxidation in streptozotocin diabetes. Gen. Physiol. Biophys. 24, 13-26.

Pére, M.-C. \& Etienne, M., 2007. Insulin sensitivity during pregnancy, lactation, and postweaning in primiparous gilts. J. Anim. Sci. 85, 101-109. https://doi.org/10.2527/jas.2006-130.

Pinos-Rodríguez, J.M., Velázquez, J.C., González, S.S., Aguirre, J.R., García, J.C., Álvarez, G. \& Jasso, Y., 2010. Effects of cladode age on biomass yield and nutritional value of intensively produced spineless cactus for ruminants. S. Afr. J. Anim. Sci. 40, 245-250. http://dx.doi.org/10.4314/sajas.v40i3.14.

Quesnel, H., Meunier-Salaün, M.-C., Hamard, A., Guillemet, R., Etienne, M., Farmer, C., Dourmad, J.Y. \& Père, M.-C., 2009. Dietary fiber for pregnant sows: influence on sow physiology and performance during lactation. J. Anim. Sci. 87, 532-43. https://doi.org/10.2527/jas.2008-1231.

Rempel, L.A., Vallet, J.L., Lents, C.A. \& Nonneman, D.J., 2015. Measurements of body composition during late gestation and lactation in first and second parity sows and its relationship to piglet production and post-weaning reproductive performance. Livest. Sci. 178, 289-95. https://doi.org/10.1016/j.livsci.2015.05.036.

Sanchez, R.E.P., Ochoa, G. O., Caratachea, A.J., Bravo, R.M.R. \& Rodriguez, R.O., 2016. Validation of a commercial hand-held human electronic glucose meter for use in pigs. Int. J. Pure. App. Biosci. 4, 1-7. http://dx.doi.org/10.18782/2320-7051.2364.

Sánchez, R.E.P., Ochoa, G.O., Caratachea, A.J., Valladares, A.G. \& Rodríguez, R.O., 2015. Efecto del número de parto sobre el consumo de alimento voluntario de las cerdas durante la fase de lactancia y su repercusión en el intervalo destete-estro. Nota técnica. Rev. Cient. 25, 145-52.

Sinclair, A.G., Shaw, J.M., Edwards, S.A., Hoste, S. \& McCartney, A., 1999. The effect of dietary protein level on milk yield and composition and piglet growth and composition of Meishan synthetic and European White breeds of sow. Anim. Sci. 68, 701-08. https://doi.org/10.1017/S1357729800050724.

Thingnes. S.L., Ekker, A.S., Gaustad, A.H. \& Framstad, T., 2012. Ad libitum versus step-up feeding during late lactation: The effect on feed consumption, body composition and production performance in dry fed loose housed sows. Livest. Sci. 149, 250-59. https://doi.org/10.1016/j.livsci.2012.07.015.

Van den Brand, H., Heetkamp, M.J., Soede, N.M., Schrama, J.W. \& Kemp, B., 2000. Energy balance of lactating primiparous sows as affected by feeding level and dietary energy source. J. Anim. Sci. 78, 1520-1528. https://doi.org/10.2527/2000.7861520x.

Viñoles, C., Meikle, A. \& Martin, G.B., 2008. Short-term nutritional treatments grazing legumes or feeding concentrates increase prolificacy in Corriedale ewes. Anim. Rep. Sci. 113, $82-92$. https://doi.org/10.1016/j.anireprosci.2008.05.079.

Wood, P.D.P., 1967. Algebraic model of the lactation curve in cattle. Nature 216, $164-165$. https://doi.org/10.1038/216164a0.

Wynne, K., Stanley, S., McGowan, B. \& Bloom, S., 2005. Appetite control. J. Endocrinol. 184, $291-318$. https://doi.org/10.1677/joe.1.05866.

Ylönem, K., Saloranta, C., Kronberg-Kippila, C., Goop, L., Aro, A. \& Virtanen, S.M., 2003. Association of dietary fibre with glucose metabolism in nondiabetic relatives of subjects with Type 2 diabetes. The Botnia Dietary Study 26, 1979-85. https://doi.org/10.2337/diacare.26.7.1979.

Yoder, D.L., Schwab, C.R., Fix, J.S., Duttlinger, V.M. \& Baas, T.J., 2012. Lactation feed intake in purebred and F1 sows and its relationship with reproductive performance. Livest. Sci. 50, $187-99$. https://doi.org/10.1016/j.livsci.2012.08.019. 